\title{
Serotonin 5-HT4 Agonist Activity of a Series of Meso- Azanoradamantane Benzamides
}

\author{
Daniel Becker \\ Loyola University Chicago, dbecke3@luc.edu
}

Roger Nosal

Clara I. Villamil

Gary Gullikson

Follow this and additional works at: https://ecommons.luc.edu/chemistry_facpubs

Part of the Chemistry Commons

Author Manuscript

This is a pre-publication author manuscript of the final, published article.

\section{Recommended Citation}

Becker, Daniel; Nosal, Roger; Villamil, Clara I.; and Gullikson, Gary. Serotonin 5-HT4 Agonist Activity of a Series of Meso-Azanoradamantane Benzamides. Bioorganic \& Medicinal Chemistry Letters, 17, 1: , 1997. Retrieved from Loyola eCommons, Chemistry: Faculty Publications and Other Works, http://dx.doi.org/ 10.1016/S0960-894X(97)00408-3

This Article is brought to you for free and open access by the Faculty Publications and Other Works by Department at Loyola eCommons. It has been accepted for inclusion in Chemistry: Faculty Publications and Other Works by an authorized administrator of Loyola eCommons. For more information, please contact ecommons@luc.edu. cc) (i) $\Theta$

This work is licensed under a Creative Commons Attribution-Noncommercial-No Derivative Works 3.0 License. (c) 1997 Elsevier 


\title{
SEROTONIN 5-HT4 AGONIST ACTIVITY OF A SERIES OF MESO-AZANORADAMANTANE BENZAMIDES
}

\author{
Daniel P. Becker, ${ }^{a *}$ Roger Nosal, ${ }^{a}$ Clara I. Villamil, ${ }^{a}$ Gary Gullikson, ${ }^{b}$ \\ Chafiq Moummi, ${ }^{b}$ Dai-Chang Yang, ${ }^{b}$ and Daniel L. Flynn, ${ }^{a^{*}}$ \\ Departments of Medicinal Chemistry a and Pharmacology,, \\ Searle Research \& Development, 4901 Searle Parkway, Skokie, IL 60077
}

\begin{abstract}
A series of meso-amino(methyl)azanoradamantane benzamides have been prepared and evaluated for $5-\mathrm{HT}_{4}$ agonism activity in the rat tunica muscularis mucosae (TMM) assay. Compound $\mathbf{8 i}$ is the most potent $5-\mathrm{HT}_{4}$ agonist in the series, with an $\mathrm{EC}_{50}$ of $217 \mathrm{nM}$.
\end{abstract}

The serotonin 5- $\mathrm{HT}_{4}$ receptor has been identified in a variety of tissues and mediates an impressive array of functional responses. ${ }^{1}$ The $5-\mathrm{HT}_{4}$ receptor was first described by Dumuis and Bockaert ${ }^{2}$ in mouse embryo colliculi neurons and by Craig and Clarke $^{3}$ in guinea-pig ileum. Furthermore, agonist activity at this receptor has been correlated with gastrointestinal prokinetic activity of prokinetic benzamides, including metoclopramide, zacopride, cisapride and renzapride. ${ }^{4}$ Novel and potent 5- $\mathrm{HT}_{4}$ agonists have potential in treating gastrointestinal motility disorders including reflux esophagitis, non-ulcer dyspepsia (NUD) and the irritable bowel syndrome (IBS). Continuing efforts in this area have led to a number of potent agonists for the 5- $\mathrm{HT}_{4}$ receptor. ${ }^{5}$

In earlier communications ${ }^{6}$ we disclosed a series of azaadamantane and azanoradamantane benzamides, including the potent $5-\mathrm{HT}_{4}$ agonist/5- $\mathrm{HT}_{3}$ antagonist, $\mathrm{SC}-52491$, which has an $\mathrm{EC}_{50}$ of $51 \mathrm{nM}$ in the tunica muscularis mucosae assay and a $\mathrm{K}_{\mathrm{i}}$ of $1.2 \mathrm{nM}$ at the $5-\mathrm{HT}_{3}$ receptor. SC-52491 is also highly selective versus other monoamine receptors, with $\mathrm{IC}_{50} \mathrm{~s}>10,000 \mathrm{nM}$ for serotonin 5- $\mathrm{HT}_{1}$ and 5- $\mathrm{HT}_{2}$ receptors; dopamine $\mathrm{D}_{1}$ and $\mathrm{D}_{2}$ receptors; alpha-1, alpha- 2 and beta adrenergic receptors; as well as muscarinic and substance $\mathrm{P}$ receptors. We previously described the synthesis of the anti-4(R)-amino derivative of azacycle $\mathbf{I}^{6 a, 7}$ for the preparation of SC-52491, which contains four contiguous asymmetric centers. We subsequently focussed our attention on a series of azanoradamantanes as serotonergics in order to capitalize on their conformationally rigid structure to produce analogs with high potency and selectivity. We were specifically attracted to achiral substituted azanoradamantane scaffolds which exhibit a plane of symmetry. Benzamides produced from these scaffolds would obviate the need for either asymmetric synthesis or resolution.

Figure I
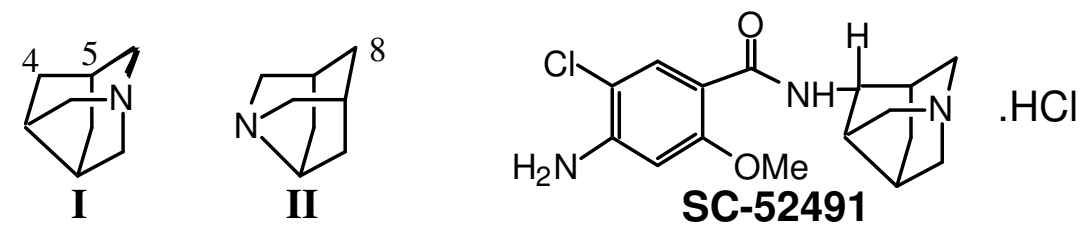

The azanoradamantane skeleton possesses two nonequivalent bridgehead positions. Incorporation of a nitrogen atom at either of these two bridgehead positions leads to two isomeric azanoradamantanes, I and II (Figure I). Both $\mathbf{I}$ and $\mathbf{I I}$ belong to the $\mathrm{C}_{\mathrm{S}}$ symmetry group and as such are meso-structures. This symmetry is retained if substitution is made at the 5-position on azanoradamantane $\mathbf{I}$ or at the 8-position of azanoradamantane II.

Compounds containing the meso-azanoradamantane skeleton of type I have not been reported in the literature. Azanoradamantanes of type II had previously been synthesized by Speckamp, ${ }^{8}$ and this skeleton is 
present in natural products, including (+)-aristofruticosane. ${ }^{9}$

Herein we describe the $5-\mathrm{HT}_{4}$ and $5-\mathrm{HT}_{3}$ properties of novel benzamide derivatives of amino(alkyl) derivatives of both isomeric mesoazanoradamantanes I and II. The requisite amino(alkyl)azanoradamantanes are shown in Figure II.

Figure II
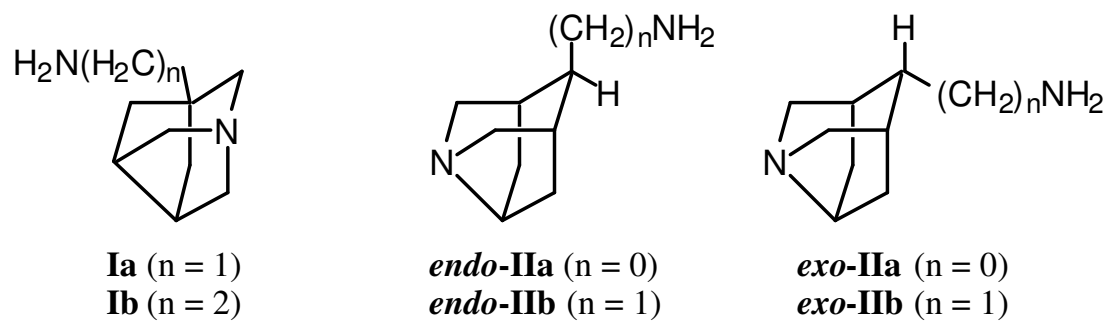

The aminomethylazanoradamantane Ia was prepared as shown in Scheme I. Reduction of 1, ${ }^{7}$ prepared by our tandem atom-transfer radical cyclization/ionic cyclization methodology, was reduced with lithium borohydride to give the diol 2. Treatment with an excess of tosyl chloride gave the bis-tosylate which was deprotected with trifluoroacetic acid and cyclized with cesium chloride to give the azanoradamantane tosylate $\mathbf{3}$ in excellent yield. Displacement of the neopentyl tosylate with azide followed by reduction with lithium aluminum hydride gave aminomethyl azanoradamantane Ia.

The homologated derivative Ib was prepared via treatment of the azanoradamantane tosylate $\mathbf{3}$ with potassium cyanide followed by reduction with lithium aluminum hydride to give the aminoethyl azanoradamantane Ib (Scheme II).

\section{Scheme I}

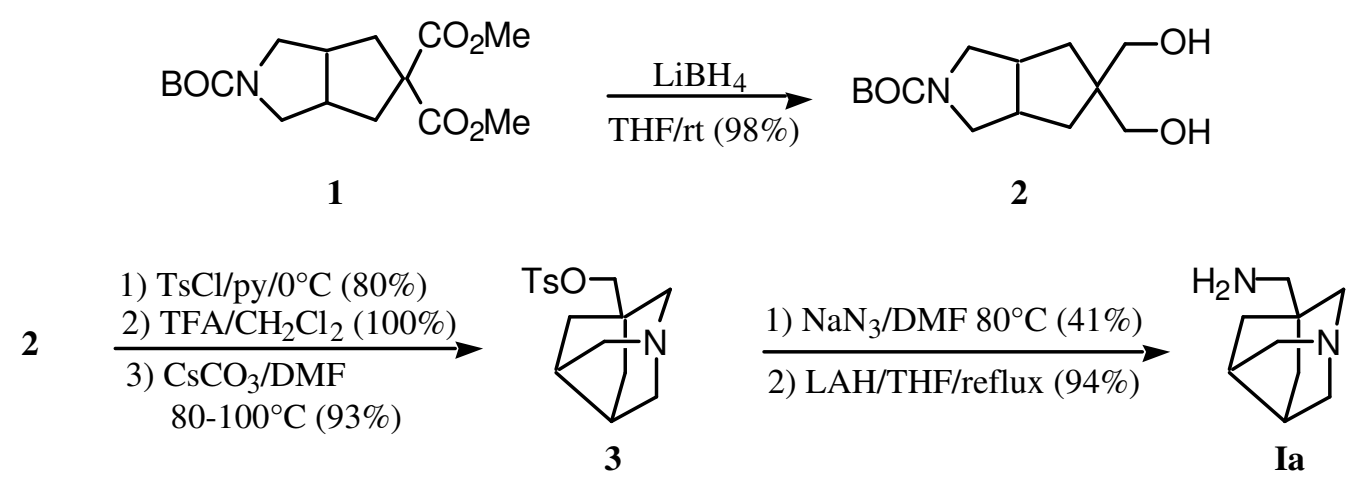

Scheme II

$3 \quad \frac{1) \mathrm{KCN} / \mathrm{KI} / \mathrm{DMF} / 80^{\circ} \mathrm{C}(37 \%)}{2) \mathrm{LAH} / \mathrm{THF} / \mathrm{reflux}(98 \%)}$

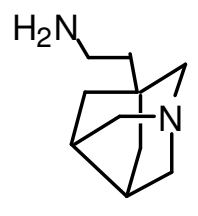

Ib

The isomeric endo- and exo-aminoazanoradamantanes of type II were prepared from azanoradamantanone $4^{8}$ by reduction of the O-benzyloxime to give endo- 10 and exo-IIa ${ }^{10}$ as a $1: 1$ mixture (Scheme III). Alternatively, reductive homologation of azanoradamantone 4 with tosylmethyl isocyanide (TosMIC), ${ }^{11}$ as we had done previously on 1-azaadamantan-4-one, ${ }^{12}$ gave the isomeric endo- and exo-nitriles 5 which were separable by flash chromatography on silica gel. Subsequent reduction with lithium aluminum 
hydride on each nitrile isomer separately gave the corresponding aminoazaadamantanes endo-IIb and exo-IIb, respectively.

With the requisite amino(methyl)azanoradamantanes in hand, it remained to couple these amines with the appropriate benzoic acid derivative as shown in Scheme IV. 4-Acetamido-5-chloro-2-methoxybenzoic acid 6 was treated with 1,1'-carbonyldiimidazole (CDI) followed by the appropriate amino(alkyl)azanoradamantane $\left(\mathrm{Z}-\mathrm{NH}_{2}\right)$ followed by deprotection with methanolic potassium hydroxide (except for $\mathbf{8 f}-\mathbf{h}$, which were tested as the acetamides). More conveniently, 4-amino-5-chloro-2-methoxybenzoic acid 7 can be treated directly with $\mathrm{CDI}$ followed by the appropriate amine to give the benzamide $\mathbf{8}(\mathrm{R}=\mathrm{H})$.

\section{Scheme III}
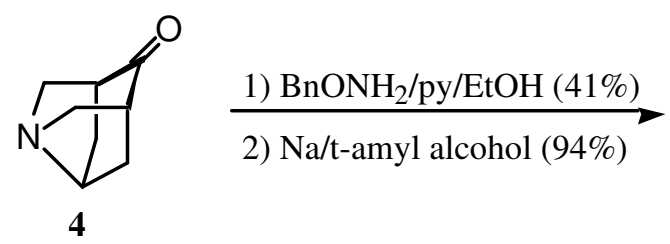

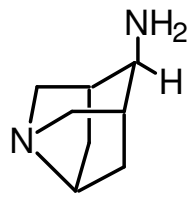

endo-IIa

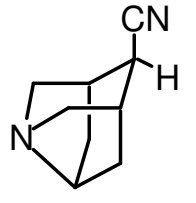

$$
\begin{aligned}
& \text { endo-5 } \\
& \downarrow \begin{array}{l}
\mathrm{LAH} / \mathrm{THF} \\
(94 \%)
\end{array}
\end{aligned}
$$<smiles>NCC1CN2CCC1C2</smiles>
endo-IIb<smiles>NC1CN2CCC1C2</smiles>

exo-IIa
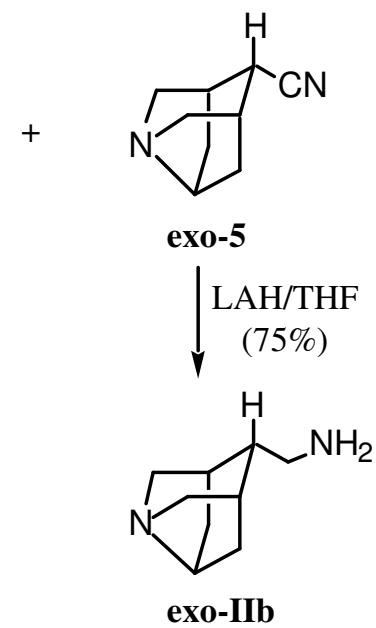

\section{Scheme IV}<smiles>[R]Nc1cc(OC)c(C(=O)O)cc1Cl</smiles>

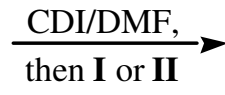

$6 \mathrm{R}=\mathrm{A}$ $7 \mathrm{R}=\mathrm{H}$<smiles>[Z]C(=O)c1cc(Cl)c(N)cc1OC</smiles>

8a-j

The 5-HT 4 agonist activities are summarized in Table I, and SC-52491 (8a) is included as a reference standard. The endo derivative $\mathbf{8 b}$ showed modest $5-\mathrm{HT}_{4}$ agonist activity in the rat tunica muscularis mucosae assay $^{13}$ with an $\mathrm{EC}_{50}$ of $712 \mathrm{nM}$, but the exo isomer $\mathbf{8 b}$ was twice as potent with an $\mathrm{EC}_{50}$ of $382 \mathrm{nM}$. We observed that epimeric homologation increases the potency in the azaadamantane series. ${ }^{12}$ However, the 5$\mathrm{HT}_{4}$ agonist potency was comparable for $\mathbf{8 d}$ and $\mathbf{8 c}$.

The corresponding acetamide derivatives $\mathbf{8 f}, \mathbf{8 g}$, and $\mathbf{8 h}$ (1:1 epimeric mixture) were essentially devoid of 5- $\mathrm{HT}_{4}$ activity. The acetamide $\mathbf{8 f}$ did exhibit rather weak 5- $\mathrm{HT}_{4}$ agonism (3.3 uM) and the unparallel slope observed for this compound suggested that this analog may have been acting as a partial agonist. It is not known if these compounds have 5- $\mathrm{HT}_{4}$ antagonist activity. 
The derivative 8i was the most potent meso-azanoradamantane examined in this study, exhibiting an $\mathrm{EC}_{50}$ of $217 \mathrm{nM}$. The homolog $\mathbf{8 j}$ was almost an order of magnitude less potent.

Azanoradamantane benzamide 8i was selected for further study on the basis of its more potent 5- $\mathrm{HT}_{4}$ agonist activity. The compound is also a potent $5-\mathrm{HT}_{3}$ antagonist, having a $\mathrm{K}_{\mathrm{i}}$ of $5.0(0.5) \mathrm{nM}$ in the $5-\mathrm{HT}_{3}$ binding assay of Kilpatrick, ${ }^{14}$ and exhibiting $70 \%$ inhibition of the serotonin $5-\mathrm{HT}_{3}$-mediated bradycardia in the Bezold-Jarisch reflex model ${ }^{15}$ in mice at $1 \mathrm{mpk}$ after I.P. administration. The compound was selective with respect to binding at the dopamine $\mathrm{D}_{2}$ receptor $\left(\mathrm{IC}_{50}>10,000 \mathrm{nM}\right)$.

In summary, we have synthesized two new series of amino(alkyl)azanoradamantane benzamides which exhibit 5-HT 4 agonism as well as affinity for the 5- $\mathrm{HT}_{3}$ receptor. SC-55387 was the most potent 5-HT4 agonist in the present study with an $\mathrm{IC}_{50}$ of $217 \mathrm{nM}$ in the rat TMM assay and a $\mathrm{K}_{\mathrm{i}}$ of 5.0 (0.5) nM at the 5$\mathrm{HT}_{3}$ receptor. These meso-compounds have the distinct advantage of being achiral, although the compounds of the present series were not as potent as SC-52491 in 5-HT 4 agonist activity or 5-HT 3 antagonist activity.

Table I 


\begin{tabular}{|c|c|c|c|}
\hline Compound & Z & $\mathrm{R}$ & $\begin{array}{c}5-\mathrm{HT}_{4} \text { Agonism } \\
\text { EC50 (nM) } \\
\end{array}$ \\
\hline $\begin{array}{c}8 a \\
\text { SC-52491 }\end{array}$ & & $\mathrm{H}$ & $51.3(6.6)$ \\
\hline $8 b$ & & $\mathrm{H}$ & 711.6 (83.7) \\
\hline $8 c$ & & $\mathrm{H}$ & $382.0(24.1)$ \\
\hline $8 d$ & & $\mathrm{H}$ & 420.7 (87.2) \\
\hline $8 e$ & & $\mathrm{H}$ & $660(126.3)$ \\
\hline $8 f$ & & Ac & 3335 (225) \\
\hline $8 g$ & & Ac & $>10,000$ \\
\hline $8 h$ & & Ac & $>10,000$ \\
\hline $8 i$ & & $\mathrm{H}$ & 216.8 \\
\hline $8 j$ & & $\mathrm{H}$ & $1658(77)$ \\
\hline
\end{tabular}


1) a) Hoyer, D.; Clarke, D.E.; Fozard, J.R.; Hartig, P.R.; Martin, G.R.; Mylecharane, E.J.; Saxena, P.R., and Humphrey, P.P.A. Pharmacol. Rev. 1994, 46, 157-203. b) Ford, A.P.D.W. and Clarke, D.E., Med. Res. Rev. 1993, 13, 633-62. c) Bockaert, J.; Fozard, J.R.; Dumuis, A. and Clarke, D.E., Trends Pharmacol. Sci. 1992, 13, 141-5.d) Tonini, M.; Rizzi, C.A.; Manzo, L. and Onori, L., Pharmacol. Res. 1991, 24, 5-14. e) Turconi, M.; Schiantarelli, P.; Borsini, F.; Rizzi, C.A.; Ladinsky, H.; and Donetti, A. Drugs of the Future 1991, 16, 1011-26.

2) Dumuis, A.; Bouhelal, R.; Sebben, M.; Cory, R. and Bockaert, J. Mol. Pharmacol. 1988, 34, 880-7.

3) a) Craig, D.A. and Clarke, D.E., Br. J. Pharmacol. 1989, 96,247P. b) Craig, D.A.; Clarke, D.E.; J. Pharmacol. Exp. Ther. 1990, 252, 1378.

4) a) Dumuis, A.; Sebben, M.; Bockaert, J., Naunyn-Schmiedeberg's Arch. Pharmacol. 1989, 340, 403. b) Craig, D.A. and Clarke, D.E. Br. J. Pharmacol. 1991, 102, 563-4. c) Buchheit, K.-H. and Buhl, T. Eur. J. Pharmacol. 1991, 205, 203-8.

5) a) Our previous work resulted in SC-53116, the first selective 5-HT 4 agonist: Flynn, D.L.; Zabrowski, D. L.; Becker, D.P.; Nosal, R.; Villamil, C. I.; Gullikson, G. W.; Moummi, C.;Yang, D.-C.; J. Med. Chem. 1992, 35, 1486-9. b) King, F.D.; Hadley, M.S.; Joiner, K.T.; Martin, R.T.; Sanger, G.J.; Smith, D.M.; Smith, G.E.; Smith, P.; Turner, D.H.; and Watts, E.A., J. Med. Chem. 1993, 36, 683. c) Langlois, M.; Zhang, L.; Yang, D.; Bremont, B.; Shen, S.; Manara, L.; and Croci, T., Bioorg. Med. Chem. Lett. 1994, 4, 1433-

6) a) Flynn, D.L.; Becker, D.P.; Spangler, D.P.; Nosal, R.; Gullikson, G.W.; Moummi, C.; and Yang, D.-C. Bioorg. Med. Chem. Lett. 1992, 2, 1613-8. b) Becker, D.P.; Goldstin, B.; Gullikson, G.W.; Loeffler, R.; Moormann, A.; Moummi, C.; Nosal, R.; Spangler, D.; Villamil, C.I.; Yang, D.-C.; Zabrowski, D.L.; Flynn, D.L. in "Perspectives in Receptor Research", ed. D. Giardina et. al., Pharmacochemistry Library, Vol 24, Elsevier Science B. V.: Amsterdam, 1996, pp. 99-120.

7) Flynn, D.L.; Becker, D.P.; Nosal, R.; Zabrowski, D.L., Tet. Lett. 1992, 33, 7283-6.

8) a) Bok, T.R.; Speckamp, W.N. Heterocycles 1979, 12, 343. b) Speckamp, W.N.; Dujkink, J.; Dekkers, A.W.J.D.; Huisman, H.O., Tetrahedron, 1971, 27, 3143-56. c) Bok, Th.R. and Speckamp, W.N., Tetrahedron, 1979, 35, 267-72.

9) Bick, I. C. R. and Hai, M. A. in "The Alkaloids", Ed. A. Brossi, Academic Press, New York, 1985, Vol XXIV.

10) Endo and exo correspond to syn and anti, respectively (with respect to the ring nitrogen. Endo and exo also correspond to IUPAC designations of (r) and (s)-isomers, respectively, denoting the pseudoasymmetric centers of substitution: Nomenclature of Organic Chemistry, Sections A, B, D, E, F and H, 1979 Edition, section E-4.12, pp 482 and 489.

11) Oldenziel, O.H.; van Leusen, D.; van Leusen, A.M. J. Org. Chem. 1977, 42, 3114.

12) Flynn, D.L; Shone, R.L.; U.S. patent application serial number 07/919,679. WO 94/02482, February 3, 1994.

13) Baxter, G.S.; Craig, D.A.; Clarke, D.E.; Naunyn-Schmiedeberg's Arch. Pharmacol. 1991, 343, 439-446.

14) The assay of Kilpatrick was employed using ${ }^{3} \mathrm{H}-\mathrm{GR} 65630$ as the radioligand with male rat cortical tissue. Kilpatrick, G.J.; Jones, B.J.; Tyers, M.B.; Nature, 1987, 330, 746.

15) Saxena, P.R.; Lawang, A.; Int. Pharmacodyn. 1985, 277, 235. 
Include in text or in references or at all??? NO

PanLabs IC50@ 5-HT4

SC-5586739\%@500 nM

SC-5631925\%@500 nM

SC-5538731\%@500nM

cisapride $\quad 100 \mathrm{nM}(\mathrm{Ki}=17 \mathrm{nM})$

5HT $\quad$ IC50 $=300 \mathrm{nM}(\mathrm{Ki}=50 \mathrm{nM})$

$\mathrm{R}, \mathrm{S}$-zac $\quad \mathrm{IC} 50=1270 \mathrm{nM}(\mathrm{Ki}=210 \mathrm{nM})$

6) b) Becker, D.P.; Gullikson, G.W.; Moummi, C.; Yang, D.-C., and Flynn, D.L.; Bioorg. Med. Chem. Lett. 1995, 5, XXXX-XX, preceding article in this issue.

Add current addresses of Gary and Chafiq? NO

7) 1-Azaadamantane and azanoradamantane II have been reported $9 \mathrm{a}$ to have $\mathrm{pKb}$ values in water of 2.96 and 2.61, respectively, corresponding to pKa values of 11.0 and 11.4 for the corresponding conjugate acids. 